\title{
HUBUNGAN PENGETAHUAN K3 TERHADAP KESADARAN BERPERILAKU K3 PADA MAHASISWA DI LABORATORIUM
}

\author{
Rini Yana ${ }^{1}$ \\ ${ }^{1}$ Laboratorium Biokimia, Fakultas Kedokteran, Universitas Sriwijaya, \\ rini.yana.rh@gmail.com
}

Sumbisi: 25 Oktober 2018 ; Penerimaan: 20 Juli 2019

\begin{abstract}
ABSTRAK
Kesehatan dan Keselamatan Kerja (K3) di Laboratorium sangatlah penting untuk diterapkan. Penerapan perilaku K3 sangat ditentukan oleh pengetahuan K3. Mahasiswa belum begitu banyak pengetahuannya tentang $K 3$ di laboratoriumdan masih kurangnya kesadaran untuk berperilaku K3. Penelitian ini perlu untuk mengetahui hubungan pengetahuan K3 terhadap kesadaran berperilaku K3 pada mahasiswa FK di laboratorium. Penelitian ini menggunakan metode korelasi Pearson Product Moment atau analisis korelasi berupa data variabel untuk mengetahui hubungan variabel bebas yaitu pengetahuan K3 $(X)$, dengan variabel terikat yaitu kesadaran berperilaku K3 (Y). Teknik pengumpulan data menggunakan kuisioner dan populasi, dalam penelitian ini adalah mahasiswa Fakultas Kedokteran Universitas Sriwijaya yang sedang praktikum di laboratorium Biokimia berjumlah 229 responden. Setelah diuji terdapat hubungan antara pengetahuan $K 3$ dengan kesadaran berperilaku K3 di laboratorium $(r=0,482)$ yang tergolong cukup. Besarnya hubungan pengetahuan K3 terhadap kesadaran berperilaku K3 sebesar 23,21 \% dan sisanya 76,79\% ditentukan oleh variabel lain. Taraf signifikansi (a) sebesar $5 \%$ menunjukkan bahwa terdapat pengaruh yang positif hubungan pengetahuan K3 terhadap kesadaran berperilaku K3 mahasiswa Fakultas Kedokteran Universitas Sriwijaya di laboratorium dilihat dari nilai t hitung $>t$ tabel atau 7,25 >1,97.
\end{abstract}

Kata kunci : Pengetahuan K3; laboratorium; Mahasiswa; Kesadaran berperilaku K3.

\section{PENDAHULUAN}

Dalam melalukan aktivitas, kita memerlukan kondisi kerja yang aman, sehat dan nyaman. Untuk itu kedaan kerja seperti ini sangat diperlukan untuk menjamin bahwa perkerjaan tersebut dapat mencapai hasil kerja yang diinginkan. Dalam dunia kerja, keadaan kerja yang demikian disebut dalam istilah K3. K3 adalah singkatan dari Keselamatan dan Kesehatan Kerja yang dalam bahasa Inggrisnya disebut sebagai Occupational Health and Safety (OHS). Secara umum K3 atau OHS dapat didefinisikan sebagai suatu sistem program yang dibuat bagi pekerja dan pengusaha sebagai upaya pencegahan (preventif) timbulnya kecelakaan kerja dan penyakit akibat kerja di dalam lingkungan kerja. Dengan demikian, kita harus mengenali hal-hal yang berpotensi menimbulkan kecelakaan kerja dan penyakit akibat kerja serta tindakan antisifatif bila terjadi kecelakaan kerja (Malinasari dan Azzuri 2013).

Secara hakikat K3 merupakan suatu bidang ilmu multi disiplin yang menerapkan upaya pemeliharaan dan peningkatan kondisi lingkungan tempat kerja, mencegah terjadinya kerugian dan pencemaran lingkungan kerja (Sholihah, 2013).

Kesehatan kerja dapat diartikan sebagai suatu bentuk dari adanya jaminan kesehatan yang diberikan pada seseorang saat melakukan pekerjaan termasuk di laboratorium. Dengan demikian orang yang bekerja di laboratorium wajib mendapat jaminan kesehatan.

Kecelakaan kerja menurut Cecep (2014) adalah kejadian yang tidak 
terduga dan tidak diharapkan, karena tidak ada kesengajaan tetapi mengakibatkan kerugian dan penderitaan.

Ada banyak sekali tujuan kesehatan kerja yang ditujukan untuk yang bekerja sebagai petugas atau pengguna laboratorium. Secara umum tujuan penerapan $\mathrm{K} 3$ di laboratorium menurut AR Effendi (2018) adalah

1. Untuk melindungi tenaga laboratorium serta pengguna laboratorium lainnya dari resiko kerja.

2. Untuk memastikan bahwa seluruh peralatan dan bahan di laboratorium dalam kondisi aman untuk digunakan.

3. Untuk menjaga seluruh aktivitas di laboratorium baik praktikum, pelatihan serta penelitian dapat terlaksana dengan baik.

4. Untuk menciptakan lingkungan kerja yang aman dan nyaman.

Berdasarkan pengamatan kepada mahasiswa, K3 belum mendapat perhatian yang memadai dan belum sadar berperilaku K3 terutama ketika berada di laboratorium. Mahasiswa merasa kurang praktis menggunakan peralatan keselamatan kerja, sehingga mereka menyepelekan hal-hal yang berhubungan dengan $\mathrm{K} 3$.

Demikian juga kurangnya sosialisasi serta belum sepenuhnya memperhatikan perihal K3 serta kurang tegasnya kita menindaklanjuti mahasiswa yang melanggar.

Kesadaran berperilaku K3 harus ditanamkan kepada semua mahasiswa, salah satu caranya dengan memberikan pendidikan kesehatan dan keselamatan kerja (K3), sehingga dapat bersikap positif terhadap K3.

Untuk itu dapat diambil kesimpulan bahwa K3 sangat penting untuk diterapkan karena dapat menjamin keamanan dan keselamatan bagi pekerja tenaga laboratorium dan mahasiswa sebagai pengguna laboratorium. Juga menjamin keamanan dan keselamatan sarana dan prasarana yang penting di laboratorium.

\section{TUJUAN}

Tujuan yang ingin dicapai dalam penelitian ini adalah untuk mengetahui hubungan pengetahuan K3 terhadap kesadaran berperilaku K3 padamahasiswadi laboratorium.

\section{LATAR BELAKANG}

K3 belum mendapat perhatian yang memadai dari semua pihak, antara lain pada mahasiswa yang masih kurangpengetahuan K3 serta belum sadar untuk berperilaku K3 di laboratorium

\section{METODE PENELITIAN}

Menurut Arikunto (2010) Metode penelitian adalah cara yang digunakan oleh peneliti dalam mengumpulkan data penelitian. Sedangkan menurut Sugiyono (2014) Metode Penelitian merupakan cara ilmiah untuk mendapatkan data dengan tujuan dan kegunaan tertentu. Metode penelitian yang dilakukan dalam penelitian adalah deskriptif dengan jenis korelasional. Metode korelasi adalah metode penelitian yang berusaha menghubungkan antara satu unsure dengan unsur lain untuk menciptakan bentuk baru yang berbeda dari sebelumnya, Sugiyono (2014). Jenis penelitian yang digunakan adalah penelitian korelasional karena mengidentifikasi hubungan dari suatu variabel terhadap variabel lain. Metode yang digunakan adalah Peason Product Moment (PPM) atau analisa korelasi data variabel untuk mengetahui variabel bebas $(\mathrm{X})$ yaitu pengetahuan $\mathrm{K} 3$ dengan variabel terikat (Y)yaitu kesadaran 
berperilaku K3. Sehingga penelitian ini hanya menjelaskan data sesuai fakta berdasarkan pengukuran pada responden.

Angka korelasi berkisar antara -1 s/d +1 semakin mendekati 1 maka korelasi semakin mendekati sempurna. Sementara nilai negative dan positif mengindikasihkan arah hubungan. Yang positif menandakan bahwa pola hubungan searah atau semakin tinggi (X) menyebabkan kenaikan pula (Y) sebagai variabel.

Interprestasi angka korelasi menurut Prof. Sugiyono (2007)

$$
\begin{aligned}
& 0-0,199 \quad \ldots \ldots . . \text { SangatLemah } \\
& 0,20-0,399 \quad \ldots \ldots . . \text { Lemah } \\
& 0,40-0,599 \quad \ldots \ldots . \text { Sedang } \\
& 0,60-0,799 \quad \ldots \ldots . \text { Kuat } \\
& 0,80-1,0 \quad \ldots \ldots . \text { SangatKuat }
\end{aligned}
$$

Korelasi Pearson ini biasanya digunakan untuk mengetahui hubungan pada dua variabel, dengan mensyaratkan data terdistribusi normal.

Rumus yang digunakan adalah sebagai berikut :

$$
r=\frac{n \sum X Y-\left(\sum X\right)\left(\sum Y\right)}{\sqrt{\left(n \sum(X)^{2}-\left(\sum X\right)^{2}\right)\left(n \sum(Y)^{2}-\left(\sum Y\right)^{2}\right)}}
$$

(Riduwan, 1997; 123)

Keterangan :

$r=$ Koefisien korelasi

$\Sigma \mathrm{X}=$ Jumlah skor variabel bebas

$\sum Y=$ Jumlah skor variabel terikat

Variabel Penelitian adalah segala sesuatu yang ditetapkan oleh peneliti untuk dipelajari sehingga diperoleh informasi tentang hal tersebut, lalu ditarik kesimpulannya, Sugiyono (2015). Dalam hal ini variabel bebas adalah pengetahuan $\mathrm{K} 3(\mathrm{X})$ sedangkan variabel terikatnya adalah kesadaran berperilaku K3 (Y).

Apabila koefisien korelasi dikuadratkan, akan menjadi koefisien penentu (KP) atau koefisien determinasi, yang artinya penyebab perubahan pada variabel $Y$ yang datang dari variabel $X$, sebesar kuadrat koefisien korelasinya. Koefisien penentu ini menjelaskan besarnya pengaruh nilai variabel $X$ terhadap naik turunnya variabel $Y$. untuk menyatakan besar kecilnya sumbangan $X$ terhadap $Y$ dapat ditentukan dengan rumus diterminan sebagai berikut :

$\mathrm{KP}=\mathrm{r}^{2} \times 100 \%$

Dimana :

$\mathrm{KP}=$ Besarnya koefisien penentu (determinan)

$r=$ Koefisien korelasi

Untuk mengetahui apakah signifikan pengetahuan $\mathrm{K} 3$ dengan kesadaran berperilaku K3 dengan menguji rumus thitung

$$
t_{\text {hitung }}=r \frac{\sqrt{n-2}}{\sqrt{\left(1-r^{2}\right.}}
$$

Keterangan :

$r=$ KoefisienKorelasi

$\mathrm{n}=$ Jumlah Responden

( $\mathrm{n}-2=\mathrm{db}$, derajat bebas)

Kaidah pengujiannya :

Jika $t_{\text {hitung }} \geq$ dari $t_{\text {tabel }}$, maka signifikan

Jika $t_{\text {hitung }} \leq$ dari $t_{\text {tabel }}$, maka tidak signifikan

Kemudian tingkat kesalahan $(\alpha)=$ 0,05 dengan rumus derajad bebas $(\mathrm{db})$ $=\mathrm{n}-2$

Tempat dan Waktu Penelitian, Penelitian ini dilakukan di Laboratorium Biokimia Fakultas Kedokteran Universitas Sriwijaya di Inderalaya. Waktu penelitian dilakukan pada awal bulan September 2018.

Populasi yang menjadi objek penelitian ini adalah mahasiswa baru Fakultas Kedokteran angkatan 2018 yang akan mengikuti praktikum Kimia Medik.

Teknik pengumpulan data dilakukan dengan kuisioner, dengan memberikan seperangkat pertanyaan 
yang tertulis kepada respoden untuk dijawabnya, Sugiyono (2015).

Kuisioner dalam penelitian ini digunakan untuk mengetahui variabel pengetahuan K3 dan kesadaran berperilaku $\mathrm{K} 3$ di laboratorium pada mahasiswa Fakultas Kedokteran Universitas Sriwijaya dengan jumlah responden sebanyak 229 mahasiswa. Pertanyaan dibuat dengan berpedoman pada indikator variabel-variabel penelitian ini dalam beberapa butir soal.

Pengetahuan K3 adalah kemampuan untuk mengetahui dan mendapat informasi-informasi berkaitan dengan kesehatan dan keselamatan kerja yang diperoleh dari hasil penglihatan dan pendengaran. Untuk kisi-kisi pembuatan pertanyaan dari pengetahuan $\mathrm{K} 3$ yaitu diberikan pertanyaan mengenai pemahaman, pengertian dan tujuan $\mathrm{K} 3$, identifikasi faktor penyebab kecelakaan kerja, dan menguraikan cara pencegahan kecelakaan serta pentingnya penggunaan APD saat bekerja di laboratorium.

Kesadaran berperilaku K3 adalah kesadaran dari dalam diri seseorang untuk menerapkan prosedur K3. Untuk kisi-kisi pertanyaan kesadaran berperilaku K3 adalah perilaku bertanggung jawab terhadap diri sendiri, perilaku bertanggung jawab terhadap lingkungan, mentaati peraturan yang ada di laboratorium dan perilaku terhadap bahaya fisik dan psikologis.

\section{HASIL DAN PEMBAHASAN}

Tabel 1. Hasil variabel pengetahuan $\mathrm{K} 3(\mathrm{X})$ dan kesadaran berprilaku $\mathrm{K} 3(\mathrm{Y})$

\begin{tabular}{cccccc}
\hline $\mathbf{n}$ & $\sum \mathbf{X}$ & $\sum \mathbf{Y}$ & $\sum \mathbf{X}^{2}$ & $\sum \mathbf{Y}^{2}$ & $\sum \mathbf{X Y}$ \\
\hline & & & & & \\
229 & 10185 & 10416 & 454863 & 476688 & 464389
\end{tabular}

Sebelum dilakukan pengujian data diasumsikan bahwa data ini memenuhi persyaratan yaitu, berdistribusi normal, data dipilih secara acak (random), dan data mempunyai pasangan yang sama.

Untuk mendapatkan nilai koefisien korelasi ( $r$ ) adalah

$$
\begin{aligned}
& r=\frac{n \sum X Y-\left(\sum X\right)\left(\sum Y\right)}{\sqrt{\left(n \sum(X)^{2}-\left(\sum X\right)^{2}\right)\left(n \sum(Y)^{2}-\left(\sum Y\right)^{2}\right)}} \\
& r=0,482 \text { Jadi, terdapat hubungan antara }
\end{aligned}
$$
pengetahuan $\mathrm{K} 3$ dengan kesadaran berperilaku K3 di laboratorium, dimana hasil interpretasi koefisien korelasi $(r=$ 0,482 ) tergolong cukup kuat.

Adapun nilainya berkisar antara $1 \leq r \leq+1$, nilai $r= \pm 1$ dikatakan korelasi sempurna sedangkan $r=0$ berarti tidak adanya korelasi antara kedua variabel. Tanda positif dan negatif dari sebuah nilai korelasi menunjukkan arah dari korelasi tersebut, Jika nilai $r$ bertanda positif dikatakan hubungan kedua variabel adalah searah atau positif,sedangkan jika nilai $r$ negatif dikatakan hubungan kedua variabel adalah berlawanan arah atau negatif, dan dapat dilihat pada gambar 1 .

Setelah nilai koefisien korelasi diperoleh, nilai koefisien determinasi juga dapat diperoleh dengan persamaan $\mathrm{KP}=\mathrm{r}^{2} \times 100 \%=23,210 \%$

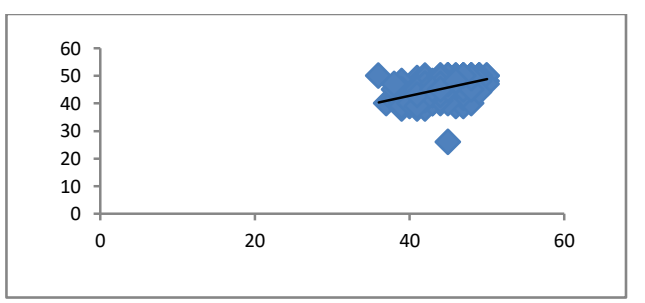

Gambar 1. Hubungan pengetahuan $\mathrm{K} 3$ terhadap kesadaran berperilaku $\mathrm{K} 3$, yaitu korelasi positif

Nilai KP pada persamaan diatas menunjukkan seberapa besar nilai variabel bebas yaitu pengetahuan $\mathrm{K} 3$ mempengaruhi nilai variabel terikat yaitu kesadaran berperilaku K3 pada mahasiswa di laboratorium. 
Nilai $(1-\mathrm{KP})$ akan menunjukkan persentase besarnya pengaruh faktorfaktor lain diluar faktor yang ada pada variabel bebas, dalam mempengaruhi variabel terikat.

Artinya pengaruh hubungan pengetahuan $\mathrm{K} 3$ terhadap kesadaran berperilaku K3 sebesar 23,210\% dan sisanya $76,790 \%$ ditentukan oleh variabel lain.

Untuk mengetahui apakah ada hubungan yang signifikan antara pengetahuan $\mathrm{K} 3$ terhadap kesadaran berperilaku K3 mahasiswa di laboratorium dengan langkah pengujian sebagai berikut, yaitu menentukan hipotesis, dimana

$\mathrm{H}_{\mathrm{a}}$ : Terdapat hubungan antara pengetahuan $\mathrm{K} 3$ dengan kesadaran berperilaku $\mathrm{K} 3$

$\mathrm{H}_{\mathrm{o}}$ : Tidak terdapat hubungan antara pengetahuan $\mathrm{K} 3$ dengan Kesadaran berperilaku $\mathrm{K} 3$

Atau $\mathrm{H}_{\mathrm{a}}: r \neq 0$ dan $\mathrm{H}_{\mathrm{o}}: \mathrm{r}=0$

Kemudian menentukan tingkat signifikansi pengujian menggunakan uji dua sisi dengan tingkat signifikansi $\alpha=$ $5 \%$. Tingkat signifikansi dalam hal ini berarti kita mengambil resiko salah dalam mengambil keputusan untuk menolak hipotesis yang benar sebanyak-banyaknya $5 \%$ atau 0,05 adalah ukuran standar yang sering digunakan dalam penelitian.

Menentukan t hitung berdasarkan rumus diatas diperoleh nilai adalah 7,25 dan dengan ketentuan tingkat kesalahan $\alpha=0,05$, dengan derajat kebebasan (db) $\mathrm{n}-2$ atau $229-2=227$. Sehingga $(0,05,227)$ diperoleh untuk $t$ tabel sebesar 1,97 (pada tabel t) atau dapat dicari di Ms Exel dengan ketik = $\operatorname{tinv}(0.05,227)$ lalu enter.

Dari pengujian ini $\mathrm{H}_{0}$ ditolak jika $\mathrm{t}$ hitung $<\mathrm{t}$ tabel atau $\mathrm{t}$ hitung $>\mathrm{t}$ tabel, oleh karena nilai $t$ hitung $>t$ tabel atau $7,25>1,97$ artinya bahwa korelasi variabel $X$ dengan $Y$ atau hubungan pengetahuan $\mathrm{K} 3$ dengan kesadaran berperilaku K3 pada mahasiswa di laboratorium adalah signifikan.

\section{KESIMPULAN}

Setelah diuji terdapat hubungan antara pengetahuan $\mathrm{K} 3$ terhadap kesadaran berperilaku K3 di laboratorium $(r=0,482)$ yang tergolong cukup.

Besarnya hubungan pengetahuan K3 terhadap kesadaran berperilaku K3 sebesar $23,21 \%$ dan sisanya $76,79 \%$ ditentukan oleh variabel lain.

Taraf signifikansi $(\alpha)$ sebesar $5 \%$ menunjukkan bahwa terdapat pengaruh yang positif hubungan pengetahuan $\mathrm{K} 3$ terhadap kesadaran berperilaku K3 mahasiswa di laboratorium, dilihat dari nilai t hitung $>t$ tabel atau 7,25 >1,97.

\section{DAFTAR PUSTAKA}

Effendi, A. 2018. K3 Laboratorium Pendidikan, Bandar Lampung.

Sucipto,CD. 2014. Kesehatan dan Keselamatan Kerja. Gosyen Publishing, Yogyakarta

Riduwan, BA. 2009. Pengantar Statistik Sosial. Alfabeta, Bandung.

Sugiyono, 2015. Metode Penelitian Pendidikan. Alfabeta, Bandung.

Sugiyono, 2017. Metode Penelitian Kuantitatif. Alfabeta, Bandung.

Internet : Koefisien determinasi, 24 Juli 2014. https://aliefworkshop.com

Internet : Cara Mendapatkan Nilai Ttabel \& F-tabel di exel 2013 Maringngerrang. http://www.maringngerarrang.com 